\title{
Honeybee immunity and colony losses
}

\author{
F. Nazzi, ${ }^{1}$ D. Annoscia, ${ }^{1}$ E. Caprio,, ${ }^{2}$ G. Di Prisco, ${ }^{2}$ F. Pennacchio ${ }^{2}$ \\ 'Dipartimento di Scienze Agrarie e Ambientali, Università di Udine; ${ }^{2}$ Dipartimento di Agraria, Sez. \\ BIPAF, Laboratorio di Entomologia E. Tremblay, Università di Napoli Federico II, Portici, Italy
}

\begin{abstract}
The decline of honeybee colonies and their eventual collapse is a widespread phenomenon in the Northern hemisphere of the globe, which severely limits the beekeeping industry. This dramatic event is associated with an enhanced impact of parasites and pathogens on honeybees, which is indicative of reduced immunocompetence. The parasitic mite Varroa destructor and the vectored viral pathogens appear to play a key-role in the induction of this complex syndrome. In particular, the Deformed Wing Virus (DWV) is widespread and is now considered, along with Varroa, one of the major causes of bee colony losses. Several lines of evidence indicate that this mite/DWV association severely affects the immune system of honeybees and makes them more sensitive to the action of other stress factors. The molecular mechanisms underpinning these complex interactions are currently being investigated and the emerging information has allowed the development of a new functional model, describing how different stress factors may synergistically concur in the induction of bee immune alteration and health decline. This pro-
\end{abstract}

Correspondence: Francesco Pennacchio, Dipartimento di Agraria, Laboratorio di Entomologia E. Tremblay, Università di Napoli Federico II, Via Università 100, 80055 Portici (NA), Italy.

Tel. +39.081 .2539195 .

E-mail: f.pennacchio@unina.it.

Key words: honeybee colony collapse, immunity, Varroa destructor, DWV, neuroimmunity, neonicotinoids.

Acknowledgments: this work was funded by the Italian Ministry of Agriculture (MiPAAF), (research project "Apenet - Ricerca e Monitoraggio in Apicoltura”) and POR Campania FSE 2007-2013, Project CARINA.

Contributions: the authors contributed equally.

Received for publication: 7 March 2014.

Accepted for publication: 12 August 2014.

This work is licensed under a Creative Commons Attribution NonCommercial 3.0 License (CC BY-NC 3.0).

(C) Copyright F. Nazzi et al., 2014

Licensee PAGEPress, Italy

Entomologia 2014; 2:203

doi:10.4081/entomologia.2014.203 vides a new logical framework in which to interpret the proposed multifactorial origin of bee colony losses and sets the stage for a more comprehensive and integrated analysis of the effect that multiple stress agents may have on honeybees.

\section{Introduction}

Mysterious die offs of honeybee colonies, characterized by peculiar symptoms, such as the absence of worker bees in presence of the queen, brood and sufficient stores, were first reported, in the USA, in 2006 (Stokstad, 2007). These unusual symptoms led to a largely shared idea of an emerging bee disease, which was named Colony Collapse Disorder (CCD) (van Engelsdorp et al., 2009). The alarming news from USA were soon followed by similar reports of colony losses from all over the Northern hemisphere, although specific CCD symptoms were not noted elsewhere (Carreck \& Neumann, 2010). Indeed, CCD is still unreported in Europe (Dainat et al., 2012) whereas it is now regarded as one of the many causes of colony losses in the USA (van Engelsdorp et al., 2012a), which are now regularly subjected to monitoring schemes set up by large consortia in Europe (Prevention of honey bee Colony Losses; Carreck \& Neumann, 2010) and in the USA (The Bee Informed Partnership; van Engelsdorp et al., 2012b). The information gathered so far indicates that losses in the range of $20-30 \%$ of colonies, mostly occurring over winter, are commonly recorded in many areas, even though much higher rates can be locally registered (van der Zee $e t$ al., 2012; van Engelsdorp et al., 2012a).

Honey bees losses have the potential of drastically reducing in a few years the number of managed colonies, with dramatic consequences for the environment and agriculture, given the fundamental contribution of animal pollinators to plant biodiversity and crop production (Klein et al., 2007). Despite a declining trend observed in North America and Europe in the second half of the last century (van Engelsdorp \& Meixner, 2010), the impact of this recent problem has been limited by the replacement of colonies lost over winter with new nuclei created in advance by beekeepers. However, caution is still necessary, as this controlled negative trend is associated with an increasing demand for crop pollination by bees (Aizen \& Harder, 2009). In addition, the concurrent decline of wild pollinators (Biesmeijer et al., 2006; Cameron et al., 2011), that play a role not yet fully recognized (Garibaldi et al., 2013), adds up more reasons of concern.

To date, the causes and the mechanisms involved in bee colony decline and eventual collapse are not fully understood. Here we briefly overview the current literature, trying to outline a general functional framework in which to analyze how different stress factors may synergistically interact to generate this dramatic event. 


\section{Honey bee colony losses and their causal agents}

The serious concerns generated by CCD prompted a rapidly increasing number of studies aiming to identify significant relationships among potential causal agents and CCD occurrence. Most of these studies correlated the state of collapsing colonies, sampled under a vast range of environmental conditions, with the presence of potential risk factors. In this way, specific stress agents, such as viruses (Cox-Foster et al., 2007), pesticides (Henry et al., 2012; Lu et al., 2012) and the microsporidian parasite Nosema ceranae (Higes et al., 2008), were identified, in different studies, as alternative factors actively inducing colony losses. However, subsequent researches often revealed that, albeit being surely involved, these factors were not the unique causal agents responsible for the observed losses. For example, Cox-Foster et al. (2007), based on a metagenomic survey of collapsing and healthy colonies across the USA, evidenced that the Israeli Acute Paralysis Virus (IAPV) was significantly related to CCD; however, a subsequent in depth study found no correlation between CCD symptoms and IAPV prevalence or load, suggesting a multifactorial origin of CCD (van Engelsdorp et al., 2009). This hypothesis was corroborated by other studies showing that, in general, more factors, constantly including parasites and pathogens, were involved in colony losses such as, for example, the mite Varroa destructor and bee viruses (Genersch et al., 2010; Nazzi et al., 2012) or viruses and Nosema (Bromenshenk et al., 2010), Nosema and pesticides (Pettis et al., 2012).

Although the mutifactorial origin of bee colony losses is now accepted by most scientists, a clear understanding of the mechanistic bases underlying this catastrophic event is still largely undefined. What is the common thread of colony losses that, under different circumstances, are associated with different stress factors? How do bees react to the multifaceted environmental challenge with a coordinated stress response against biotic and abiotic stress agents, which often show a synergic effect and result in a much higher negative impact of parasites and pathogens, often coexisting in complex associations? These are the emerging key-questions that need to be addressed.

Multiparasite communities living within the same host seem to be widespread in nature (Petney \& Andrews, 1998) and several authors have tried to tackle the challenging task of defining the rules governing such systems (Lafferty, 2010). General interpretative models of these complex systems have been also proposed. For example, Pedersen and Fenton (2007) suggested that within-host parasite communities can be represented like food webs, in which the host provides the resources for the parasites, while the immune response mounted against these invaders is conceptually coincident with the third trophic level. This is a very intriguing way of looking at the structure of the complex microcosm at organismic level. Honeybees, as social insects, are a unique model system to investigate these arguments, both at the organism and colony level.

\section{Honeybee immunity}

The large consensus on the multifactorial origin of colony collapse and its frequent association with high loads of pathogens and parasites indicates that the immune system is of central importance, and its functioning can be influenced by a number of stress factors. Before considering how stress agents can synergistically interact with the immune system, it is worth to summarize briefly our current knowledge on how insects, and bees in particular, cope with foreign invaders and enemies.

The best studied insect model system for invertebrate immunity is
Drosophila (Lemaitre \& Hoffmann, 2007; Ganesan et al., 2011; Kounatidis \& Ligoxygakis, 2012), for which both the humoral and cellular components have been well characterized. Soluble molecules (humoral) circulating in the hemolymph along with hemocytes (cellular) actively cooperate to mount a coordinated defense response, in which both arms are inextricably linked. For example, the encapsulation of large intruders, such as metazoan parasites, by hemocytes is in most cases followed by melanin synthesis on the surface of the foreign body (Lemaitre \& Hoffmann, 2007; Cerenius et al., 2008). The strict localization of melanogenesis during encapsulation, to prevent systemic toxicity, is an essential requirement which seems to be mediated, at least in Lepidoptera, by functional amyloids, apparently controlling also the capsule formation with mechanisms not yet fully understood (Falabella et al., 2012; Di Lelio et al., 2014).

Melanization, which plays a key-role in invertebrate immunity, rapidly takes place at the injury sites and on the surface of non-self objects (Cerenius et al., 2008; 2011). However, melanin, along with its toxic metabolic intermediates, is one of the multiple humoral compounds that can be synthesized upon immune challenge and released outside the cellular environment, to target parasites/pathogens entering the haemocoel (Lemaitre \& Hoffmann, 2007). Among these humoral components, lysozymes, cytokines and antimicrobial peptides (AMPs), which are largely secreted by fat body cells and haemocytes, are potent molecules acting against bacterial and fungal pathogens.

The control of viral pathogens in insects is largely dependent on RNAi (RNA interference), which is the core component of the antiviral immune barrier (Sabin et al., 2010). However, there are also additional mechanisms, controlled by transduction pathways regulated by NF- $\kappa$ B transcription factors, also involved in the antimicrobial responses mentioned above, which are essential to control specific viral infections in Drosophila (Zambon et al., 2005; Souza-Neto et al., 2009; Sabin et al., 2010).

All these defense responses, which have a significant metabolic cost, are triggered when molecular patterns typically associated with pathogens (PAMPs, Pathogen Associated Molecular Patterns) are recognized and bound by host receptors (PRRs, Pathogen Recognition Receptors) (Ronald \& Beutler, 2010), to activate specific transduction cascades.

These are general features of the immune response largely shared by insects, but a wealth of specific adaptations are present in different orders, which reflect both the evolutionary history and the environmental conditions to which they are exposed. Indeed, even though the keyelements of the innate immunity in vertebrates and invertebrates are surprisingly similar, there are a number of significant differences among different insect species.

Honeybees are social insects living in large colonies and, as such, are very much exposed to a number of pathogens and parasites, which can be transmitted very easily among densely packed population members (van Engelsdorp \& Meixner, 2010). However, the number of canonical genes controlling immune response is lower compared to Drosophila (Evans et al., 2006), but the defense barriers are reinforced by behavioral mechanisms, which are collectively denoted as social immunity (WilsonRich et al., 2009). This latter includes, for example, hygienic behavior and allo-grooming, in part controlled by external chemical signals, like cuticular hydrocarbons, which appear to be finely modulated by immune challenge (Baracchi et al., 2012; Richard et al., 2012).

The molecular and functional bases of the defense responses in honeybees have been investigated only in the last few years, in most cases with studies describing genome-wide gene expression changes induced by different immune challenges and stress factors. These descriptive studies provide excellent background information for more mechanistic analyses, aiming to unravel virulence strategies and defense countermeasures, which, however, are still understudied. An indepth review of all these descriptive studies is out of the scope of this 
paper, but we can confidently state that the most general conclusion arising from the literature is that bees exposed to parasites and pathogens show various degree of immunosuppression, even though the immune genes targeted are not always univocally affected, as can be inferred, for example, by the different papers focusing on Varroa mite induced immune alteration (Gregory et al., 2005; Yang \& Cox-Foster, 2005; Navajas et al., 2008; Zhang et al., 2010; Nazzi et al., 2012); the co-presence of viral infections vectored by mites may partly account for the reported discrepancies, as these widespread pathogens have an impact on bee immunity which is still poorly characterized. Antiviral immunity in honeybees, indeed, has received very limited attention, even though indirect evidence clearly supports the presence of a RNAi machinery effectively contrasting viral infections (Maori et al., 2009; Hunter et al., 2010; Liu et al., 2010; Desai et al., 2012). A recent study has elucidated how dsRNAs, acting as viral PAMPs, trigger an antiviral response in honeybees, which mitigates viral infection (Flenniken \& Andino, 2013). Surprisingly, the transcriptomic analysis of bees exposed to viral infection or dsRNA treatment did not show significant changes in those genes responding to viral infection in flies or mosquitoes, but a generalized and significant down-regulation of AMP encoding genes (Flenniken \& Andino, 2013), typically induced by immune challenge, via Toll, Imd or JNK signaling pathways, and under NF- $\mathrm{KB}$ transcriptional control (Evans et al., 2006). A significant transcriptional down-regulation of NF- $\kappa B$ has been reported in bees infested by Varroa mites and with high infection levels of Deformed Wing Virus (DWV) (Nazzi et al., 2012). In this study, experimental evidence also indicated that the down-regulation of NF- $\kappa \mathrm{B}$ was largely due to DWV infection and that RNAi silencing of this transcription factor promoted viral proliferation. Collectively, these experimental evidences point out the possible occurrence of virulence strategies, used by viral pathogens, which target NF- $\kappa \mathrm{B}$, likely to disable antiviral barriers activated by this transcription factor. However, this strategy inevitably influences a number of downstream physiological pathways dependent from NF-кB, which cooperatively control multifaceted and highly integrated biological responses (Hayden \& Ghosh, 2008).

\section{A model of interaction among stress factors}

The rise of colony losses has been associated with a number of causal agents, which are all apparently able to induce a sudden decline of populations and their eventual collapse. Despite the fact that a number of studies have convincingly demonstrated the key-importance of pathogens, a common infection pattern that can be univocally linked to colony collapse has not yet been identified. However, there is growing evidence showing that $V$. destructor is the greatest threat challenging bee population all over the world, which causes a severe syndrome generally denoted as Varroosis (Boecking \& Genersch, 2008; Rosenkranz et al. 2010). These direct effects are aggravated by the mite capacity to vector several viral pathogens, like DWV, KBV, SBV, ABPV and IAPV (reviewed in Chen \& Siede, 2007), which seem to play a very important role in the induction of colony collapse (Francis et al., 2013) and have been proposed as reliable predictive markers of this event, in particular DWV (Dainat et al., 2012). This latter is characterized by low virulence, compared to more aggressive viral pathogens of bees, which may account for its widespread occurrence in varroa-infested colonies, as predicted by the model proposed by Martin (2001). This model has been corroborated by an elegant study in the Hawaiian islands, where the arrival of the Varroa mite has determined a high increase of prevalence and loads of DWV and the selection of an aggressive viral strain (Martin et al., 2012). These results convincingly support the hypothesis that Varroa-DWV association may be responsible for the death of millions of colonies worldwide (Martin et al., 2012), which, indeed, are very often infected by DWV (de Miranda \& Genersch, 2010).
As stated above, colony decline and collapse are associated with pronounced immune suppression, even though the proposed active role played by Varroa (Yang \& Cox-Foster, 2007) has been questioned (Gregory et al., 2005; Navajas et al., 2008; Johnson et al., 2009; Zhang et al., 2010; Ryabov et al., 2014), while progressing DWV infections seem to mediate the adverse effects on bee immune response (Nazzi et al., 2012). However, the infection route by direct penetration into the hemocoel, either by Varroa feeding or artificial injection, is essential to trigger the intense replication of a specific viral strain (Ryabov et al., 2014).

The study by Nazzi et al. (2012) has contributed to the elucidation of the relative impact exerted by these two closely interacting stress factors, by analyzing, over time, population and molecular changes in collapsing colonies. Indeed, colonies in which mite control measures were not applied showed a steady increase of Varroa population, which was associated with a sudden increase of bee mortality in autumn. Among the many pathogens considered, only DWV showed a positive correlation with bee mortality, with viral loads exceeding $1 \times 10^{15}$ genome copies per bee when the steep mortality increase was registered in autumn. At that time, a transcriptomic analysis revealed changes in the expression level of several immune genes, with the majority of them being down-regulated, and only a few up-regulated, which included Eater-like (a protein involved in phagocytosis), as similarly reported for virus-infected bees (Flenniken \& Andino, 2013). The highest level of down-regulation was recorded for dorsal-1A, a gene encoding for a member of the NF- $\mathrm{KB}$ protein family (Evans et al., 2006). The transcription of this gene was adversely affected by the virus, but not by Varroa infestation in the absence of the virus, and its silencing promoted DWV replication (Nazzi et al., 2012); this body of experimental evidence indicates that the viral defenses activated by NF- $\kappa \mathrm{B}$ are of crucial importance and are likely targeted by DWV virulence strategies.

Many viruses are able to target this transcription factor, which is involved in the regulation of a number of responses to environmental stress agents and pathogens (Hayden \& Ghosh, 2008; Mohamed \& McFadden, 2009; Strand, 2012). Viral pathogens of vertebrates or invertebrates often disrupt NF- $\mathrm{B}$ signaling by irreversibly targeting upstream events controlling the activation of this transcription factor (Thoetkiattikul et al., 2005; Falabella et al., 2007; Mohamed \& McFadden, 2009; Strand 2012). However, the virulence strategy adopted by DWV seems to be characterized by less pronounced effects on NF-KB and reflects its tight adaptation to a social insect, which could be easily destroyed by a very aggressive attack, with obvious negative consequences on viral fitness. Therefore, DWV low virulence could be in part due to its mild impact on NF- $\kappa \mathrm{B}$, which remains functional but available at reduced levels as a consequence of its transcriptional down-regulation. This effect may partly account for the delicate balance underlying the covert infection of DWV (de Miranda \& Genersch, 2010), but represents the Achille's heel of an infected colony. Indeed, any disturbing stress, which activates pathways dependent from NF-кB may compete for the use of this limitedly available transcription factor and, therefore, may adversely affect the antiviral defenses under its control. The molecular framework allowed the definition of a stress model, which is structured around delicate immune described above balance and postulates that any environmental challenge requiring NF- $\kappa \mathrm{B}$ to activate a response pathway may adversely affect antiviral immunity depending from this transcription factor and promote the proliferation of covert DWV infections (Nazzi et al., 2012). Therefore, feeding activity of Varroa mites, by activating immune responses induced by feeding wounds and penetrating pathogens, further depletes the NF- $\mathrm{BB}$ cellular pools and promotes viral replication (Nazzi et al., 2012), as already known and widely reported in literature (reviewed in de Miranda \& Genersch, 2010). This functional analysis seems to be further corroborated by an alternative interpretation of the DWV replication induced by the injection in bees of dead bacteria (Yang \& Cox-Foster, 2005), 
which, by activating NF- $\kappa$ B dependent genes encoding AMPs (Evans et al., 2006), trigger immune pathways that compete for the use of this transcription factor and may allow viral proliferation.

The DWV-mediated immunosuppression, mild and non-destructive, could be one of the major functional constraints accounting for the tight association of this virus with Varroa mites. Indeed, the negative effect exerted by the virus on NF- $\mathrm{B}$ signaling can have beneficial effect on the vector mite, as it may depress the NF- $\kappa$ B dependent immune responses (clotting and melanization) (Lemaitre \& Hoffman, 2007), which can impair hemolymph uptake and its nutritional use, as widely reported in the case of ectoparasitic insects (Pennacchio \& Strand, 2006). This association would represent a further example of viruses involved in mutualistic symbioses between parasitic entities aiming to overcome the defense barriers of the host they share (reviewed by White et al., 2013).

\section{Testing the model}

The invoked multifactorial origin of colony losses is likely the final result of synergistic interactions among different stress factors, but the overall mechanistic aspects involved still remain largely elusive. However, more in-depth analyses relative to specific stress agents are becoming available and allow to move forward the development of a comprehensive model that may reconcile the many scattered, and sometime contrasting, observations on bee colony collapse (van Engelsdorp et al., 2009; 2012a; van der Zee et al., 2012).

Among the different stress factors considered so far, particular attention has been devoted to the analysis of pesticide impact on bee colony health and stability, with special emphasis on neonicotinoid insecticides, which appear to have a wide range of negative effects on honeybees and bumblebees (Gill et al., 2012; Henry et al., 2012; Witehorn et al., 2012). However, many open questions remain and contrasting results are reported (reviewed by Cresswell et al., 2012). It is important to note that exposure to neonicotinoids has been found associated with a stronger impact of pathogens on bee colonies (Alaux et al., 2010; Aufauvre et al., 2012; Pettis et al., 2012), which, therefore, appear to suffer a reduced immune competence. Even though this effect has been often described, how it is functionally mediated has been poorly investigated (Cresswell et al., 2012) and only recently addressed by a mechanistic study assessing the impact of clothianidin on the insect immune response (Di Prisco et al., 2013). This insecticide up-regulates a negative modulator of NF- $\kappa$ B activation in insects, a Leucine Rich Repeat (LRR) protein, which is likely involved in the physiological down-regulation of the immune reaction, as similarly reported in different animal species (Ting \& Davis, 2005). Such an effect exerted by an agonist of the acetyl choline receptor suggests the presence in insects of neural reflex circuits controlling the immune response, as reported in vertebrates, where the down-regulation of the immune response is achieved through the inhibition of NF- $\kappa$ B activation in immune cells, mediated by acetylcholine receptor binding (reviewed in Tracey, 2009; Olofsson et al., 2012). The disturbance of this regulatory mechanism by neonicotinoids, possibly occurring in bees, stimulates the replication of DWV present in asymptomatic covert infections, as a consequence of the resulting down-regulation of antiviral barriers under NF-кB control (Di Prisco et al., 2013).

These results nicely fit into the model proposed by Nazzi et al. (2012), and provide a further opportunity for testing its validity. Basically, the neonicotinoid insecticides, by negatively modulating NF$\kappa \mathrm{B}$ signaling in insects, adversely affect antiviral immune defenses in honeybees (Figure 1). Therefore, their effect is at least in part mediated by the negative impact on this transcription factor, which is limitedly available in bees highly infected by DWV and exposed to Varroa mite feeding activity (Nazzi et al., 2012). In other words, this latter stress condition, very commonly occurring in the Northern hemisphere (Carreck \& Neumann, 2010), is further reinforced by a functional limitation of NF- $\mathrm{KB}$ induced by neonicotinoids, which aggravates the immunosuppression syndrome induced by the combined action of Varroa-virus association. This impact of different stress factors, as already discussed above, proposes a central role for NF-кB, which modulates a number of physiological and stress response pathways (Hayden \& Ghosh, 2008), and in particular innate immunity (Silverman \& Maniatis, 2001). Therefore, the functional framework proposed may account for the synergic role that many stress factors could play in the multifactorial induction of bee colony collapse, not univocally associated with a single causal agent, but often with a plethora of interacting factors, in most cases eventually resulting in reduced immune competence and pathogen proliferation.

The emerging stress model proposed by Nazzi et al. (2012) also indicates that other environmental conditions challenging bees can potentially interfere with immunity and colony health. Nutrition can be one of the major factors that may influence immunity by regulating the complex interactions between the host insect, pathogens and the gut microbiome (Ponton et al., 2013). The central role of NF- $\mathrm{KB}$ in the optimal energy allocation between metabolism and immunity in insects (DiAngelo et al., 2009; Pakpour et al., 2012) allows to foresee new scenarios on how bee colony health can be modulated by nutrition.

\section{Conclusions}

An in-depth analysis of the molecular mechanisms controlling the interactions between bees and biotic stress agents will likely provide new insights on how these latter may shape the evolution of defense strategies against invading pathogens and parasites. There is no doubt that a thorough understanding of how the immune system copes with the multiple environmental challenges is a key-area of research in a multidisciplinary effort towards a comprehensive mechanistic analysis of the synergism among interacting stress factors.

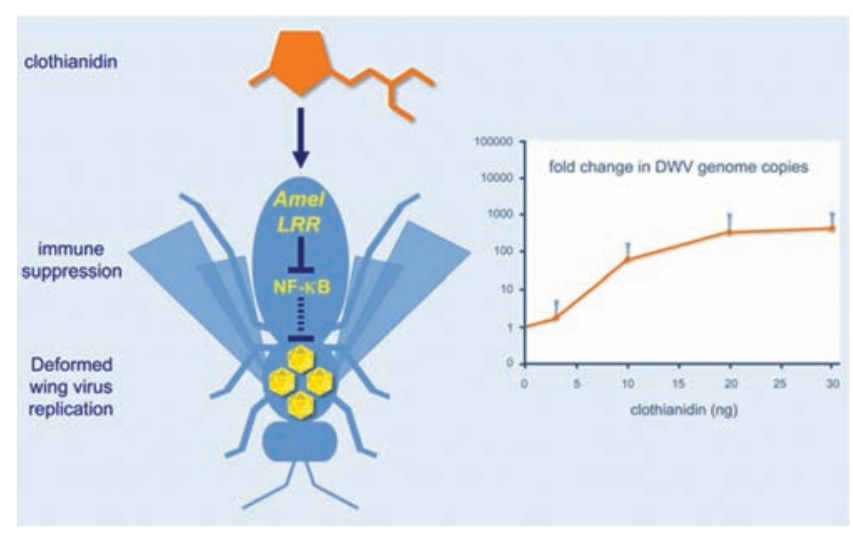

Figure 1. Effect of clothianidin on honeybee immunity and covert viral infections. Exposure of honeybees to sub-lethal doses of the neonicotinoid insecticide clothianidin upregulates a negative modulator of NF- $\kappa$ B activation (Amel/LRR) and has a negative impact on antiviral immune barriers controlled by this transcription factor. This results in increased viral replication in honeybees bearing covert infections of the Deformed wing virus, a globally distributed pathogen occurring in all colonies (data from $\mathrm{Di}$ Prisco et al., 2013). 
The negative regulation of the immune response by neonicotinoids, potent agonists of nicotinic acetylcholine receptors, indirectly demonstrates that in insects, like in mammals, the nervous system may finely tune the immune reactions. This new finding sets the stage for future studies aiming to shed light on the interplay between nervous and immune systems in insects, and on how this delicate cross-modulation can be influenced by neurotoxic insecticides and, more generally, by neurotoxic xenobiotics.

The immune alteration induced by exposure to neonicotinoid insecticides may adversely affect honeybee health, concurring, with other stress factors, in the induction of population decline and eventual collapse. In particular, the immunodeficiency caused by the combined action of Varroa-DWV association can be further enhanced by neonicotinoids. To our knowledge, the model we propose provides a new molecular framework which accounts for the multifactorial origin of honeybee colony decline and collapse, and may offer the rationale background in which to define new remedial actions to alleviate this problem. Moreover, the discovered effects of neurotoxic substances on insect immune system indicate the need of developing new and more comprehensive protocols for assessing the real impact of insecticides on honeybees.

\section{References}

AIZEN M.A., HARDER L.D., 2009 - The global stock of domesticated honey bees is growing slower than agricultural demand for pollination. - Curr. Biol. 19: 915-918.

ALAUX C., BRUNET J.L., DUSSAUBAT C., MONDET F., TCHAMITCHAN S., COUSIN M., BRILLARD J., BALDY A., BELZUNCES L.P., LE CONTE Y., 2010 - Interactions between Nosema microspores and a neonicotinoid weaken honeybees (Apis mellifera L.). - Environ. Microbiol. 12: 774-782.

AUFAUVRE J., BIRON D., VIDAU C., FONTBONNE R., ROUDEL M., DIOGON M., VIGUÈS B., BELZUNCES L., DELBAC F., BLOT N., 2012 - Parasite-insecticide interactions: a case study of Nosema ceranae and fipronil synergy on honeybee. - Sci. Rep. 2: 1-7.

BARACCHI B., FRANCESE S., TURILLAZZI S., 2012 - Evidence for antiseptic behaviour towards sick adult bees in honey bee colonies. - J. Insect Physiol. 58: 1589-1596.

BIESMEIJER J.C., ROBERTS S.P.M., REEMER M., OHLEMÜLLER R., EDWARDS M., PEETERS T., SCHAFFERS A.P., POTTS S.G., KLEUKERS R., THOMAS C.D., SETTELE J., KUNIN W.E., 2006 - Parallel declines in pollinators and insect-pollinated plants in Britain and the Netherlands. - Science 313: 351-354.

BOECKING 0., GENERSCH E., 2008 - Varroosis - the ongoing crisis in bee keeping. - J. Verbrauch. Lebensm. 3: 221-228.

BROMENSHENK J.J., HENDERSON C.B., WICK C.H., STANFORD M.F., ZULICH A.W., JABBOUR R.E., DESHPANDE S.V., MCCUBBIN P.E., SECCOMB R.A., WELCH P.M., WILLIAMS T., FIRTH D.R., SKOWRONSKI E., LEHMANN M.M., BILIMORIA S.L., GRESS J., WANNER K.W., CRAMER R.A., 2010 - Iridovirus and microsporidian linked to honey bee colony decline. - PLoS ONE 5: el3181.

CAMERON S.A., LOZIER J.D., STRANGE J.P., KOCH J.B., CORDES N., SOLTER L.F., GRISWOLD T.L., 2011 - Patterns of widespread decline in North American bumble bees. - Proc. Natl. Acad. Sci. U.S.A. 108: 662-667.

CARRECK N., NEUMANN P., 2010 - Honey bee colony losses. - J. Apicult. Res. 49: 1-6.

CERENIUS L., LEE B.L., SÖDERHÄLL K., 2008 - The proPO-system: pros and cons for its role in invertebrate immunity. - Trends Immunol. 29: $263-271$.

CERENIUS L., SÖDERHÄLL K., 2011 - Coagulation in invertebrates. - J. Innate Immun. 3: 3-8.
CHEN Y.P., SIEDE R., 2007 - Honey bee viruses. - Adv. Virus Res. 70: 33-80. COX-FOSTER D.L., CONLAN S., HOLMES E.C., PALACIOS G., EVANS J.D., MORAN N.A., QUAN P.L., BRIESE T., HORNIG M., GEISER D.M., MARTINSON V., VAN ENGELSDORP D., KALKSTEIN A.L., DRYSDALE A., HUI J., ZHAI J.H., CUI L.W., HUTCHISON S.K., SIMONS J.F., EGHOLM M., PETTIS J.S., LIPKIN W.I., 2007 - A metagenomic survey of microbes in honey bee colony collapse disorder. - Science 318: 283-287.

CRESSWELL J., CRESSWELL E., PAGE C.J., UYGUN M.B., HOLMBERGH M., LI Y., WHEELER J.G., LAYCOCK I., POOK C.J., HEMPEL DE IBARRA N., SMIRNOFF N., TYLER C.R., 2012 - Differential sensitivity of honey bees and bumble bees to a dietary insecticide (imidacloprid). - Zoology 115: 365-371.

DAINAT B., VANENGELSDORP D., NEUMANN P., 2012 - Colony collapse disorder in Europe. - Environ. Microbiol. Rep. 4: 123-125.

DE MIRANDA J., GENERSCH E., 2010 - Deformed wing virus. - J. Invertebr. Pathol. 103: S48-S61.

DESAI S., EU Y.J., WHYARD S., CURRIE R.W., 2012 - Reduction in deformed wing virus infection in larval and adult honey bees (Apis mellifera L.) by double-stranded RNA ingestion. - Insect mol. Biol. 21: 446-455.

DIANGELO J.R., BLAND M.L., BAMBINA S., CHERRY S., BIRNBAUM M.J., 2009 - The immune response attenuates growth and nutrient storage in Drosophila by reducing insulin signaling. - Proc. Natl. Acad. Sci. U.S.A. 106: 20853-20858.

DI LELIO I., VARRICCHIO P., DI PRISCO G., MARINELLI A., LASCO V., CACCIA S., CASARTELLI M., GIORDANA B., RAO R., GIGLIOTTI S., PENNACCHIO F., 2014 - Functional analysis of an immune gene of Spodoptera littoralis by RNAi. - J. Insect Physiol. 64: 90-97.

DI PRISCO G., CAVALIERE V., ANNOSCIA D., VARRICCHIO P., CAPRIO E., NAZZI F., GARGIULO G., PENNACCHIO F., 2013 - Neonicotinoid clothianidin adversely affects insect immunity and promotes replication of a viral pathogen in honey bees. - Proc. Natl. Acad. Sci. U.S.A. 110: 18466-18471.

EVANS J.D., ARONSTEIN K., CHEN Y.P., HETRU C., IMLER J.L., JIANG H., KANOST M., THOMPSON G.J., ZOU Z., HULTMARK D., 2006 Immune pathways and defence mechanisms in honey bees Apis mellifera. - Insect Mol. Biol. 15: 645-656.

FALABELLA P., RIVIELLO L., PASCALE M., DI LELIO I., TETTAMANTI G., GRIMALDI A., IANNONE C., MONTI M., PUCCI P., TAMBURRO A.M., DEEGUILEOR M., GIGLIOTTI S., PENNACCHIO F., 2012 - Functional amyloids in insect immune response. - Insect Biochem. Mol. Biol. 42: 203-211.

FALABELLA P., VARRICCHIO P., PROVOST B., ESPAGNE E., FERRARESE R., GRIMALDI A., DE EQUILEOR M., FIMIANI G., URSINI M.V., MALVA C., DREZEN J.M., 2007 - Characterization of the IkappaBlike gene family in polydnaviruses associated with wasps belonging to different Braconid subfamilies. - J. Gen. Virol. 88: 92-104.

FLENNIKEN L., ANDINO R., 2013 - Non-specific dsRNA-mediated antiviral response in the honey bee. - PLoS ONE 8: e77263.

FRANCIS R.M., NIELSEN S.L., KRYGER P., 2013 - Patterns of viral infection in honey bee queens. - J. Gen. Virol. 94: 668-676.

GANESAN S., AGGARWAL K., PAQUETTE N., SILVERMANET N., 2011 - NF$\kappa \mathrm{B} /$ Rel proteins and the humoral immune responses of Drosophila melanogaster. - Curr. Top. Microbiol. Immunol. 349: 25-60.

GARIBALDI L.A., STEFFAN-DEWENTER I., WINFREE R., AIZEN M.A., BOMMARCO R., CUNNINGHAM S.A., KREMEN C., CARVALHEIRO L.G., HARDER L.D., AFIK 0., BARTOMEUS I., BENJAMIN F., BOREUX V., CARIVEAU D., CHACOFF N.P., DUDENHÖFFER J.H., FREITAS B.M., GHAZOUL J., GREENLEAF S., HIPÓLITO J., HOLZSCHUH A., HOWLETT B., ISAACS R., JAVOREK S.K., KENNEDY C.M., KREWENKA K.M., KRISHNAN S., MANDELIK Y., MAYFIELD M.M., MOTZKE I., MUNYULI T., NAULT B.A., OTIENO M., PETERSEN J., PISANTY G., POTTS S.G., RADER R., RICKETTS 
T.H., RUNDLÖF M., SEYMOUR C.L., SCHÜEPP C., SZENTGYÖRGYI H., TAKI H., TSCHARNTKE T., VERGARA C.H., VIANA B.F., WANGER T.C., WESTPHAL C., WILLIAMS N., KLEIN A.M., 2013 - Wild pollinators enhance fruit set of crops regardless of honey bee abundance. - Science 339: 1608-1611.

GENERSCH E., EVANS J.D., FRIES I., 2010 - Honey bee disease overview. - J. Invertebr. Pathol. 103: S2-S4.

GILL J., RAMOS-RODRIGUEZ 0., RAINEL N.E., 2012 - Combined pesticide exposure severely affects individual- and colony-level traits in bees. - Nature 491: 105-108.

GREGORY G., EVANS J.D., RINDERER T., DE GUZMAN L., 2005 Conditional immune-gene suppression of honeybees parasitized by Varroa mites. - J. Insect Sci. 5: 1-7.

HAYDEN M.S., GHOSH S., 2008 - Shared principles in NF-kappaB signaling. - Cell 132: 344-362.

HENRY M., BÉGUIN M., REQUIER F., ROLLIN 0., ODOUX J.F., AUPINEL P., APTEL J., TCHAMITCHIAN S., DECOURTYE A., 2012 - A common pesticide decreases foraging success and survival in honey bees. Science 336: 348-350.

HIGES M., MARTÍN-HERNÁNDEZ R., BOTÍAS C., BAILÓN E.G., GONZÁLEZ-PORTO A.V., BARRIOS L., DEL NOZAL M.J., BERNAL J.L., JIMÉNEZ J.J., PALENCIA P.G., MEANA A., 2008 - How natural infection by Nosema ceranae causes honeybee colony collapse. Environ. Microbiol. 10: 2659-2669.

HUNTER W., ELLIS J., VANENGELSDORP D., HAYES J., WESTERVELT D., GLICK E., WILLIAMS M., SELA I., MAORI E., PETTIS J., COXFOSTER D., PALDI N., 2010 - Large-scale field application of RNA interference (RNAi) technology to reduce impact of Israeli Acute Paralysis Virus (IAPV) induced disease in honey bees (Apis mellifera), Hymenoptera: Apidae. - PLoS Pathog. 6: e1001160.

JOHNSON R.M., EVANS J.D., ROBINSON G.E., BERENBAUMET M.R., 2009 - Changes in transcript abundance relating to colony collapse disorder in honey bees (Apis mellifera). - Proc. Natl. Acad. Sci. U.S.A. 106: 14790-14795.

KLEIN A.M., VAISSIÈRE B.E., CANE J.H., STEFFAN-DEWENTER I., CUNNINGHAM S.A., KREMEN C., TSCHARNTKE T., 2007 Importance of pollinators in changing landscapes for world crops. Proc. R. Soc. B 274: 303-313.

KOUNATIDIS I., LIGOXYGAKIS P., 2012 - Drosophila as a model system to unravel the layers of innate immunity to infection. - Open Biol 2: 120075 .

LAFFERTY K.D., 2010 - Interacting parasites. - Science 330: 187-188.

LEMAITRE B., HOFFMANN J., 2007 - The host defense of Drosophila melanogaster. - Annu. Rev. Immunol. 25: 697-743.

LIU X., ZHANG Y., YAN X., HANT R., 2010 - Prevention of Chinese sacbrood virus infection in Apis cerana using RNA interference. Curr. Microbiol. 61: 422-428.

LU C., WARCHOL K.M., CALLAHAN R.A., 2012 - In situ replication of honey bee colony collapse disorder. - Bull. Insectol. 65: 99-106.

MAORI E., PALDI N., SHAFIR S., KALEV H., TSUR E., GLICK E., SELA I., 2009 - IAPV, a bee-affecting virus associated with colony collapse disorder can be silenced by dsRNA ingestion. - insect. Mol. Biol. 18: 55-60.

MARTIN S.J., 2001 - The role of Varroa and viral pathogens in the collapse of honey bee colonies: a modelling approach. - J. Appl. Ecol. 38: 1082-1093.

MARTIN S.J., HIGHFIELD A.C., BRETTELL L., VILLALOBOS E.M., BUDGE G.E., POWELL M., NIKAIDO S., SCHROEDER D.C., 2012 Global honey bee viral landscape altered by a parasitic mite. Science 336: 1304-1306.

MOHAMED M.R., MCFADDEN G., 2009 - NFkB inhibitors: strategies from poxviruses. - Cell Cycle 8: 3125-3132.

NAVAJAS M., MIGEON A., ALAUX C., MARTIN-MAGNIETTE M.L., ROBINSON G., EVANS J.D., CROS-ARTEIL S., CRAUSER D., LE
CONTE Y., 2008 - Differential gene expression of the honey bee Apis mellifera associated with Varroa destructor infection. - BMC Genomics 9: 301.

NAZZI F., BROWN S.P., ANNOSCIA D., DEL PICCOLO F., DI PRISCO G., VARRICCHIO P., DELLA VEDOVA G., CATTONARO F., CAPRIO E., PENNACCHIO F., 2012 - Synergistic parasite-pathogen interactions mediated by host immunity can drive the collapse of honeybee colonies. - PLoS Pathog. 8: e1002735.

OLOFSSON P.S., ROSAS-BALLINA M., LEVINE Y.A., TRACEY K.J., 2012 Rethinking inflammation: neural circuits in the regulation of immunity. - Immunol. Rev. 248: 188-204.

PAKPOUR N., CORBY-HARRIS V., GREEN G.P., SMITHERS H.M., CHEUNG K.W., RIEHLE M.A., LUCKHART S., 2012 - Ingested human insulin inhibits the mosquito NF-KB-dependent immune response to Plasmodium falciparum. - Infect. Immun. 80: 2141-2149.

PEDERSEN A.B., FENTON A., 2007 - Emphasizing the ecology in parasite community ecology. - Trends Ecol. Evol. 22: 133-139.

PENNACCHIO F., STRAND M.R., 2006 - Evolution of developmental strategies in parasitic Hymenoptera. - Annu. Rev. Entomol. 51: 233-258.

PETNEY T.N., ANDREWS R.H., 1998 - Multiparasite communities in animals and humans: frequency, structure and pathogenic significance. - Int. J. Parasitol. 28: 377-393.

PETTIS J.S., VANENGELSDORP D., JOHNSON J., DIVELY G., 2012 Pesticide exposure in honey bees results in increased levels of the gut pathogen Nosema. - Naturwissenschaften 99: 153-158.

PONTON F., WILSON K., HOLMES A.J., COTTER S.C., RAUBENHEIMER D., SIMPSON S.J., 2013 - Integrating nutrition and immunology: a new frontier. - J. Insect Physiol. 59: 130-137.

RICHARD F.J., HOLT H., GROZINGER C.M., 2012 - Effects of immunostimulation on social behavior, chemical communication and genome-wide gene expression in honey bee workers (Apis mellifera). - BMC Genomics 13: 558.

RONALD P.C., BEUTLER B., 2010 - Plant and animal sensors of conserved microbial signatures. - Science 330: 1061-1064.

ROSENKRANZ P., AUMEIER P., ZIEGELMANN B., 2010 - Biology and control of Varroa destructor. - J. Invertebr. Pathol. 103: S96-S119.

RYABOV E.V., WOOD G.R., FANNON J.M., MOORE J.D., BULL J.C., CHANDLER D., MEAD A., BURROUGHS N., EVANS D.J., 2014 - A virulent strain of Deformed Wing Virus (DWV) of honeybees (Apis mellifera) prevails after Varroa destructor-mediated, or in vitro, transmission. - PLOS Pathog. 10: e1004230.

SABIN S.L.R., HANNA S.L., CHERRY S., 2010 - Innate antiviral immunity in Drosophila. - Curr. Opin. Immunol. 22: 4-9.

SILVERMAN N., MANIATIS T., 2001 - NF-kappaB signaling pathways in mammalian and insect innate immunity. - Genes Dev. 15: 2321-2342.

SOUZA-NETO J.A., SIM S., DIMOPOULOS G., 2009 - An evolutionary conserved function of the JAK-STAT pathway in anti-dengue defense. - Proc. Natl. Acad. Sci. U.S.A. 106: 17841-17846.

STOKSTAD E., 2007 - The case of the empty hives. - Science 316: 970-972.

STRAND M.R., 2012 - Polydnavirus gene products that interact with the host immune system. - In: BECKAGE N.B., DREZEN J.M., (eds). Polydnaviruses. Elsevier, San Diego, pp 137-145.

THOETKIATTIKUL H., BECK M.H., STRAND M.R., 2005 - Inhibitor kappaB-like proteins from a polydnavirus inhibit NF-kappaB activation and suppress the insect immune response. - Proc. Natl. Acad. Sci. U.S.A. 102: 11426-11431.

TING J.P.Y., DAVIS B.K., 2005 - CATERPILLER: a novel gene family important in immunity, cell death, and diseases. - Annu. Rev. Immunol. 23: 387-414.

TRACEY K.J., 2009 - Reflex control of immunity. - Nat. Rev. Immunol. 9: 418-428.

VAN DER ZEE R., PISA L., ANDONOV S., BRODSCHNEIDER R., CHARRIERE J.D., CHLEBO R., COFFEY M.F., DAHLE B., GAJDA A., GRAY A., DRAZIC M.M., HIGES M., KAUKO L., KENCE A., KENCE M., 
KEZIC N., KIPRIJANOVSKA H., KRALJ J., KRISTIANSEN P., HERNANDEZ R.M., MUTINELLI F., NGUYEN B.K., OTTEN C., OZKIRIM A., PERNAL S.F., PETERSON M., RAMSAY G., SANTRAC V., SOROKER V., TOPOLSKA G., UZUNOV A., VEJSNAES F., WEI S., WILKINS S., 2012 - Managed honey bee colony losses in Canada, China, Europe, Israel and Turkey, for the winters of 2008-9 and 2009-10. J. Apic. Res. 51: 100-114.

VAN ENGELSDORP D., MEIXNER M.D., 2010 - A historical review of managed honey bee populations in Europe and the United States and the factors that may affect them. - J. Invertebr. Pathol. 103: S80-S95.

VAN ENGELSDORP D., BAYLIS K., CARON D.M., CONNELL J., DELAPLANE K.S., DONOHUE S., ESAIAS W., GROSS B., HAYES J., LENGERICH E.J., PETTIS J., RENNICH K., ROSE R., SKINNER J., SPIVAK M., TARPY D.R., UNDERWOOD R., WILKES J., 2012b - The bee informed partnership: using beekeeper's real world experience to solve beekeepers' real world problems. - Am. Entomol. 58: 116-118.

VAN ENGELSDORP D., CARON D., HAYES J., UNDERWOOD R., HENSON M., RENNICH K., SPLEEN A., ANDREE M., SNYDER R., LEE K., ROCCASECCA K., WILSON M., WILKES J., LENGERICH E., PETTIS J., 2012a - A national survey of managed honey bee 2010-11 winter colony losses in the USA: results from the Bee Informed Partnership. - J. Apic. Res. 51: 115-124.

VAN ENGELSDORP D., EVANS J.D., SAEGERMAN C., MULLIN C., HAUBRUGE E., NGUYEN B.K., FRAZIER M., FRAZIER J., COX-FOSTER D., CHEN Y., UNDERWOOD R., TARPY D.R., PETTIS J.S., 2009
- Colony collapse disorder: a descriptive study. - PLoS ONE 4: e6481. WHITE J.A., GIORGINI M., STRAND M.R., PENNACCHIO F., 2013 Arthropod symbiosis and evolution. - In: MINELLI A., BOXSHALL G., FUSCO G., (eds). Arthropod biology and evolution. Springer-Verlag, Heidelberg, pp 441-447.

WHITEHORN P.R., O'CONNOR S., WACKERS F.L., GOULSONET D., 2012 - Neonicotinoid pesticide reduces bumble bee colony growth and queen production. - Science 336: 351-352.

WILSON-RICH N., SPIVAK M., FEFFERMAN N.H., STARKS P.T., 2009 Genetic, individual, and group facilitation of disease resistance in insect societies. - Annu. Rev. Entomol. 54: 405-423.

YANG X., COX-FOSTER D., 2005 - Impact of an ectoparasite on the immunity and pathology of an invertebrate: evidence for host immunosuppression and viral amplification. - Proc. Natl. Acad. Sci. U.S.A. 102: 7470-7475.

YANG X., COX-FOSTER D., 2007 - Effects of parasitization by Varroa destructor on survivorship and physiological traits of Apis mellifera in correlation with viral incidence and microbial challenge. Parasitology 134: 405-412.

ZAMBON R., NANDAKUMAR M., VAKHARIA V.N., WU L.P., 2005 - The Toll pathway is important for an antiviral response in Drosophila. Proc. Natl. Acad. Sci. U.S.A. 102: 7257-7262.

ZHANG Y., LIU X., ZHANG W., HAN R., 2010 - Differential gene expression of the honey bees Apis mellifera and A. cerana induced by Varroa destructor infection. - J. Insect Physiol. 56: 1207-1218. 